\title{
EFEKTIFITAS AROMATHERAPY LEMON TERHADAP PENGURANGAN NYERI PERSALINAN, LAMA PERSALINAN KALA II DAN FETAL OUTCOME
}

\section{Laurena Ginting, SST, M.Kes ${ }^{1}$, Masta Melati Hutahaean, SST, M.Kes ${ }^{2}$, Lenny Lusia Simatupang, S.Kep, Ns, M.Kep ${ }^{3}$}

\author{
1,2,3 STIKes MURNI TEGUH \\ Jl Jawa No. 2 Gg. Buntu Kec Medan Timur, Kota Medan \\ e-mail : Laurenaginting2087@gmail.com
}

DOI : https://doi.org/10.35451/jkk.v2i1.245

\begin{abstract}
Pain is an unpleasant and complex condition. The fear of labor pain causes a reduction in blood flow and oxygen to the uterus giving rise to uterine inertia (inadequate contraception). Lemon aromatherapy has anesthetic, analgesic and sedative effect. The purpose of this study was to examine the effectiveness of lemon aromatherapy on pain reduction, length of labor and fetal outcome. The design of this study used a quasi experimental design with a one group approach, measurements were taken in one group given treatment by giving lemon aromatherapy and comparing the second group as a control not given aromatherapy lemon. The population of all women giving birth. The sample in this study was taken by purposive sampling. The research sample consisted of 30 women giving birth, 15 giving birth treatment and 15 giving birth as a control group. Sampling was carried out with inclusion criteria, namely in the first phase of active phase, physiological labor, willing to be the subject of research, single pregnancy, presentation of the back of the head, and not yet receiving pharmacological therapy. Data analysis was done by looking at the differences in the 2 variables because the data were not normally distributed then the statistical tests used were Mann Whitney. The results of research on the effectiveness of lemon aromatherapy on labor pain $p=0.019$ where the value of $p<0.005$, the second time showed no effectiveness of lemon aromatherapy on the second time $p=0.451$ greater than $p=0.005$ in the fetal outcome showed no effectiveness of lemon aromatherapy against fetal outcome $p=1,000$ is greater than $p=0.005$.
\end{abstract}

Keywords: Aromatherapy, Lemon, Labor_Pain, Time_of _kala II, Fetal_Outcome 


\section{PENDAHULUAN}

Nyeri persalinan adalah suatu keadaan yang tidak menyenangkan dan kompleks yang merupakan fenomena yang sangat individual dengan komponen sensorik dan emosional. Ibu hamil biasanya khawatir terhadap nyeri yang akan mereka hadapi saat persalinan serta bagaimana mereka akan bereaksi terhadap nyeri dan untuk mengatasi rasa sakit tersebut. Situasi dan kondisi dalam menghadapi nyeri ini sangat individual, sehingga menyebabkan pengalaman rasa nyeri berbeda antara satu dengan yang lainnya. Rasa nyeri pada persalinan mengakibatkan pengeluaran adrenalin yang akan mengakibatkan pembuluh darah berkontriksi sehingga akan mengurangi aliran darah yang membawa oksigen ke uterus dan mengakibatkan penurunan kontraksi uterus yang akan memperpanjang waktu persalinan (Indrayani \& Djami, 2016).

Lama persalinan dipengaruhi oleh hormon kortison dimana ketika terjadi penurunan hormon ini akan mengakibatkan sintesis HSP (Heat Shock Protein) 70 meningkat sehingga dapat meningkatkan kontraksi otot rahim. Kontraksi otot rahim yang baik berperan dalam memperlancar kemajuan persalinan dan memperdek lama persalinan. Proses persalinan kala I dan lama persalinan kala II mempengaruhi fetal outcome. Penurunan nyeri kala I fase aktif memberikan pengaruh besar pada fetal outcome yang ditandai dari penilaian bugar bayi.

Rasa takut dan cemas terhadap nyeri persalinan akan merangsang pengeluaran hormon katekolamin dan steroid yang berlebihan, sehingga menyebabkan vasokontriksi yang mengakibatkan pengurangan aliran darah dan oksigen ke uterus menimbulkan inersia uteri (his/kontrasi yang tidak adekuat), aromatherapi merupakan salah satu metode nonfarmakologi yang memiliki efektifitas untuk mengurangi nyeri (Smith \& Crowther, 2011 dalam Cholifah, et. al, 2016).

Tindakan non-farmakologis banyak dipilih karena memiliki sedikit efek samping utama, relatif murah dan dapat digunakan di seluruh persalinan teknik yang digunakan salah satunya dengan aromatherapy lemon. Berdasarkan Suwanti, et.al (2018) diketahui bahwa lemon memiliki kandungan 66-80 geranil asetat, netrol, terpine $6-14 \%$, a pinene $1-4 \%$ dan mrcyne dan Limonen. Limonen adalah komponen utama dalam senyawa kimia jeruk yang dapat menghambat sistem kerja prostaglandin sehingga dapat mengurangi nyeri yang dapat menjadi anastesi yang efektif dalam pengurangan kecemasan selama proses persalinan, dimana kecemasan berakibat pada proses persalinan lama sehingga berakibat fatal pada janin (fetal outcome).

Dalam penelitian Sulastri, et.al 2015 limonene yang terkandung dalam lemon memiliki efekektifitas sebagai anastesi, analgetik dan obat penenang dengan cara kerjanya mencegah aktivitas prostaglandin dan mengurangi rasa sakit. Nyeri persalinan yang tidak disertai dengan manajemen nyeri menimbulkan dampak negatif, seperti dikemukan dalam Dolatian, et al (2011) bahwa selama persalinan rasa sakit yang berlebihan akan menyebabkan rasa takut dan kecemasan. Hal ini akan merangsang sistem saraf simpatik untuk meningkatkan sekresi ketekolamin yang juga dapat meningkatkan kadar hormon dalam darah seperti efinefrin yang akan lebih meningkatkan rasa nyeri dan berpotensi untuk memperpanjang proses persalinan. Proses persalinan yang 
berkepanjangan ini dikaitkan dengan komplikasi pada kondisi janin termasuk berkurangnya suplai oksigen ke janin sehingga berdampak pada kematian janin.

Pengukuran intensitas nyeri merupakan bagian penting dari penilaian nyeri awal dan berkelanjutan. Skala nyeri yang divalidasi membantu pengukuran nyeri. Salah satu skala yang digunakan adalah numerical rating scale (NRS) dimana intensitas nyeri berada pada skala 0 sampai 10 . Nilai 0 menunjukkan tidak ada rasa sakit dan nilai 10 bila nyeri dirasakan paling buruk menggunkan Pain Assesment Tool

Oleh sebab itu peneliti tertarik untuk melakukan penelitian dengan mengembangkannya menggunakan aromatherapy lemon dalam mengurangi nyeri, lama persalinan dan fetal outcome.

\section{Metode}

Desain penelitian ini menggunakan desain quasi experimental dengan pendekatan one group, dilakukan pengukuran pada satu kelompok yang diberikan perlakuan dengan memberikan aromatherapy lemon dan membandingkannya pada kelompok kedua sebagai kontrol dengan tidak diberikan aromatherapy lemon.

Populasi seluruh ibu yang bersalin di klinik Heny kasih. Sampel dalam penelitian ini diambil dengan purposive sampling dengan mengambil subjek penelitian dari populasi sesuai dengan kritetia peneliti. Sampel penelitian berjumlah 30 orang ibu bersalin, 15 ibu bersalin diberikan perlakuan dan 15 ibu bersalin sebagai kelompok kontrol. Pengambilan sampel dilakukan dengan kriteria inklusi yaitu inpartu kala I fase aktif, persalinan fisiologis, bersedia menjadi subjek penelitian, kehamilan tunggal, presentasi belakang kepala, dan belum mendapat therapy farmakologi

Analisa data dilakukan dengan melihat perbedaan 2 variabel dikarena data tidak berdistrubusi normal maka uji statistik yang digunakan Mann Whitney.

\section{Hasil}

Berikut penjelasan tentang karakteristik Responden

Tabel 1. Distribusi Frekuensi Responden berdasarkan Karakteristik pada kelompok Kontrol dan Intervensi

\begin{tabular}{|c|c|c|c|c|}
\hline \multirow[b]{2}{*}{ Variabel } & \multicolumn{2}{|c|}{ Kontrol } & \multicolumn{2}{|c|}{ Intervens } \\
\hline & $F$ & $\begin{array}{c}P \\
(\%)\end{array}$ & $F$ & $\begin{array}{c}P \\
(\%)\end{array}$ \\
\hline \multicolumn{5}{|l|}{ Umur } \\
\hline$<21$ Tahun & 0 & 0 & 1 & 6,7 \\
\hline 21-35 Tahun & 15 & 100 & 10 & 66,7 \\
\hline >35 Tahun & 0 & 0 & 4 & 26,7 \\
\hline Jumlah & 15 & 100 & 15 & 100 \\
\hline \multicolumn{5}{|l|}{ Pekerjaan } \\
\hline Wiraswasta & 4 & 26,7 & 2 & 13,3 \\
\hline$I R T$ & 10 & 66,7 & 11 & 73,3 \\
\hline Guru & 1 & 6,7 & 0 & 13,3 \\
\hline Karyawan & 0 & 0 & 2 & 0 \\
\hline Jumlah & 15 & 100 & 15 & 100 \\
\hline \multicolumn{5}{|l|}{ Paritas } \\
\hline Primi Para & 9 & 60 & 6 & 40 \\
\hline Multi Para & 6 & 40 & 9 & 60 \\
\hline Jumlah & 15 & 100 & 15 & 100 \\
\hline
\end{tabular}

Pada tabel.1 menunjukan mayoritas responden berdasarkan umur pada kelompok kontrol 21-35 tahun (100\%) dan intervens 21 - 35 tahun $(66,7 \%)$, berdasarkan pekerjaan pada kelompok kontrol Mayoritas IRT 10 orang $(66,7 \%)$ dan Intervensi 11 Orang $(73,3 \%)$, pada paritas menunjukkan mayoritas pada kelompok kontrol Primi Para 9 orang (60\%) dan kelompok intervensi Multi Para 9 orang (60\%) 
Tabel. 2 Distribusi Frekuensi Responden berdasarkan Nyeri Persalinan Pada kelompok Kontrol dan Intervensi

\begin{tabular}{lllll}
\hline \multirow{2}{*}{ Variabel } & \multicolumn{2}{c}{ Kontrol } & \multicolumn{2}{c}{ Intervensi } \\
\cline { 2 - 5 } & $\mathrm{F}$ & $\begin{array}{c}\mathrm{P} \\
(\%)\end{array}$ & $\mathrm{F}$ & $\begin{array}{c}\mathrm{P} \\
(\%)\end{array}$ \\
\hline Nyeri Persalinan & & & \\
\hline No Pain & 0 & 0 & 0 & 0 \\
Mild & 2 & 13,3 & 0 & 0 \\
$\begin{array}{l}\text { Moderete } \\
\text { Severe }\end{array}$ & 3 & 20 & 10 & 66,7 \\
$\begin{array}{l}\text { Very Severe } \\
\text { Worst Pain }\end{array}$ & 3 & 46,7 & 5 & 33,7 \\
$\begin{array}{l}\text { Posibble } \\
\text { Jumlah }\end{array}$ & 0 & 0 & 0 & 0 \\
\hline
\end{tabular}

Berdasarkan tabel. 2 menunjukkan mayoritan Skala Nyeri pada kelompok kontrol Severe 7 orang $(46,7 \%)$ pada kelompok Intervensi Moderete 10 orang $(66,7 \%)$

Tabel 3. Distribusi Frekuensi Responden berdasarkan Lama Kala II pada Kelompok Kontrol dan Intervensi

\begin{tabular}{lllll}
\hline \multirow{2}{*}{ Variabel } & \multicolumn{2}{c}{ Kontrol } & \multicolumn{3}{c}{ Intervensi } \\
\cline { 2 - 5 } & \multicolumn{1}{c}{$\begin{array}{c}\mathrm{P} \\
(\%)\end{array}$} & $\mathrm{F}$ & $\begin{array}{c}\mathrm{P} \\
(\%)\end{array}$ & 3 \\
\hline Lama Kala II & & & & \\
\hline $0-1,5$ jam & 15 & 100 & 15 & 100 \\
$>1,5$ jam & 0 & 0 & 0 & 0 \\
\hline Jumlah & 15 & 100 & 15 & 100 \\
\hline
\end{tabular}

Berdasarkan tabel 3 menunjukkan mayoritas lama kala II pada kelompok Kontrol adalah $0-1,5$ jam 15 orang (100\%) dan pada kelompok Intervensi adalah $0-1,5$ jam, 15 orang (100\%)
Tabel 4. Distribusi Frekuensi Responden berdasarkan Fetal Outcome pada kelompok Kontrol dan Intervensi

\begin{tabular}{lllll}
\hline \multirow{2}{*}{ Variabel } & \multicolumn{2}{c}{ Kontrol } & \multicolumn{2}{c}{ Intervensi } \\
\cline { 2 - 5 } & $F$ & $\begin{array}{c}P \\
(\%)\end{array}$ & $F$ & $\begin{array}{c}P \\
(\%)\end{array}$ \\
\hline Fetal Outcome & & & & \\
\hline Baik & 15 & 100 & 15 & $\begin{array}{l}100 \\
\text { Tidak Baik }\end{array}$ \\
\hline Jumlah & 0 & 0 & 0 & 0 \\
\hline
\end{tabular}

Berdasarkan tabel. 4 menunjukkan mayoritas fetal outcome pada kelompok Kontrol adalah Baik 15 orang $(100 \%)$ dan pada kelompok Intervensi adalah Baik 15 orang (100\%)

Tabel 5. Hasil Analisis Uji Mann Whitney efektifitas Aromatherapy lemon

\begin{tabular}{lllll}
\hline \multirow{N}{N}{} & & $\begin{array}{l}\text { Kelompok } \\
\text { Kontrol }\end{array}$ & $\begin{array}{l}\text { Kelompok } \\
\text { Intervensi }\end{array}$ & $\mathrm{p}$ \\
\cline { 3 - 5 } & Variabel & $\begin{array}{l}\text { Mean } \\
\text { Rank }\end{array}$ & $\begin{array}{l}\text { Mean } \\
\text { Rank }\end{array}$ & \\
\hline 1 & $\begin{array}{l}\text { Nyeri } \\
\text { Persalinan }\end{array}$ & 19,17 & 19,17 & 0,019 \\
\hline 2 & $\begin{array}{l}\text { Lama } \\
\text { Kala II }\end{array}$ & 16,70 & 14,39 & 0,451 \\
\hline 3 & $\begin{array}{l}\text { Fetal } \\
\text { Outcome }\end{array}$ & 15,50 & 15,50 & 1.000 \\
\hline
\end{tabular}

Tabel 5 menunjukkan adanya efektifitas aromatherapy lemon terhadap nyeri persalinan $p=0,019$ dimana nilai $p<0.05$, lama kala II menunjukkan tidak adanya efektifitas aromatherapy lemon terhadap lama kala II $p=0,451$ lebih besar dari $p<0,05$ pada fetal outcome menunjukkan tidak adanya efektifitas aromatherapy lemon terhadap fetal outcome $p=1,000$ lebih besar dari $p<0,05$.

\section{PEMBAHASAN}

Hasil Penelitian pada tabel 5 menunjukkan adanya efektifitas 
aromatherapy lemon dalam mengurangi nyeri persalinan dengan nilai $p<0,05$. Hasil penelitian ini didukung oleh Soetrisno, et al (2016) bahwa arometherapy memeliki efektifitas mengurangi nyeri bila dibandingkan dengan yang tidak diberikan aromtheapy.

Hasil penelitian Suwanti (2018) menyatakan bahwa limonen yang terkandung dalam lemon merupakan kandungan utama dalam jeruk yang memiliki efektifitas menghambat prostaglandin dalam mengurangi nyeri. Sejalan dengan penelitian Cholifah (2016) lemon dapat mengurangi nyeri persalinan pada kelompok perlakukan lebih rendah dibandingkan pada kelompok kontrol.

Pada penelitian Sulastri et.al (2015) limonene yang terkandung dalam lemon memiliki efektifitas sebagai anastesi, analgetik dan obat penenang dengan cara mencegah prostaglandin dan mengurangi rasa sakit. Sejalan dengan penelitian Lakhan et al (2016) bahwa aromatherapi dapat mengurangi rasa nyeri. Persalinan merupakan proses yang fisiologis, ibu akan merasakan nyeri selama proses persalinan. Nyeri persalinan kombinasi fisik akibat kontraksi miometrium disertai regangan sengmen bawah rahim menyatu dengan kondisi psikologis ibu selama persalinan (Indrayani \& Moudy, 2016).

Nyeri yang dirasakan ibu menyebabkan gangguan psikologis, reaksi psikologis yang ditimbulkan bersifat negatif seperti menolak persalinan normal, stres, cemas dan takut, ini disebabkan pengeluaran hormon katekolamin yang berlebihan sehingga menurunkan sirkulasi darah ke uterus dan plasenta berakibat persalinan lama, janin hipoksia dan stres pada janin (Susilarini, 2017).

Dalam Dolatian, et al (2011) bahwa selama persalinan rasa sakit yang berlebihan akan menyebabkan rasa takut dan kecemasan. Hal ini akan merangsang sistem saraf simpatik untuk meningkatkan sekresi ketekolamin yang juga dapat meningkatkan kadar hormon dalam darah seperti efinefrin yang akan lebih meningkatkan rasa nyeri dan berpotensi untuk memperpanjang proses persalinan. Proses persalinan yang berkepanjangan ini dikaitkan dengan komplikasi pada kondisi janin termasuk berkurangnya suplai oksigen ke janin sehingga berdampak pada kematian janin

Berdasarkan tabel. 5 pada lama kala II persalinan tidak adanya efektifitas pemberian aroma therapy lemon hal ini dilihat dari $p>0,05$. Sesuai dengan Yazdkhasti et, al (2016) bahwa tidak ada perbedaan lama persalinan pada ibu bersalin yang diberikan aromatherapy dengan yang tidak diberikan aromatherapi. Sejalan juga dengan Kavani et, al (2014) bahwa tidak ada efektifitas pemeberian aromtherapi pada ibu bersalin dengan lama persalinan.

Tidak sesuai dengan Soetrisno et,al (2016) bahwa aromatherapy memiliki efektifitas pada pengurangan lama persalinan. Menurut Saputra Lyndon (2104) Lama persalinan kala II 20 - 90 menit pada primi para dan Multi para kurang dari 30 menit hal ini sesuai dengan hasil penelitian bahwa mayoritas ibu yang diberikan aromatherapy lama persalinannya $0-1,5$ jam.

Dalam Dolatian, et al (2011) bahwa rasa nyeri yang berlebihan dapat meningkatkan kecemasan sehingga meransang saraf simpatik untuk meningkatkan ketokolamin dan hormon efinefrin yang dapat meningkatkan rasa nyeri dan memperpanjang proses persalinan.

Dari hasil penelitian Tabel. 5 pada fetal outcame tidak adanya efektifitas 
pemberian aroma therapy lemon hal ini dilihat dari $p>0,05$. Sesuai dengan Kavani et, al (2014) Bahwa tidak efektifitas pemberian aromatherapi dengan intrapartum outcome (fetal outcome) dimana keadaan janin yang dilahirkan dengan APGAR Score Baik.

Hal tersebut tidak sejalan dengan Soetrisno, et. al (2016) mengatakan aromatherapy memiliki efektifitas mengurangi nyeri, lama persalinan dan fetal outcame yang baik dibandingkan dengan tidak menggunakan aromatherapy.

Dalam Asuhan Persalinan Normal (2012), penilaian keadaan bayi dinyatakan baik bila bayi segera menangis, kulit kemerahan dan adanya gerak janin yang aktif. Menurut Dolatian, et al (2011) bahwa rasa sakit persalinan dapt meningkatkan ketekolamin dan hormon efinefrin yabg berdampak pada proses persalinan yang berkepanjangan sehingga dapat menimbulkan komplikasi pada janin.

\section{KESIMPULAN}

Dapat disimpulkan terdapat efektifitas aromatherapy lemon terhadap nyeri persalinan $p=0,019$ dimana nilai $p<0.05$, lama kala II dan Fetal outcome tidak adanya efektifitas aromatherapy lemon terhadap lama kala II $p=0,451$, pada fetal outcome $p=1,000$ lebih besar dari $p<0,05$.

Aromatherapy lemon sebagai alternatif dalam mengurangi nyeri selama persalinan dilakukan dengan berbasis pelayanan kesehatan. Tenaga kesehatan dapat memberikan pelayanan kesehatan tradisional yang aman dan nyaman, pelayanan yang diberikan harus sesuai dengan standar pelayanan dan prosedur yang berlaku, untuk peneliti selanjutnya mengembangkan penelitian dengan memfokuskan pada satu paritas dan pembukaan pasien (sampel yang homogen) dan membandingkan denagn aromatherapi yang lainnya.

\section{DAFTAR PUSTAKA}

Asuhan Persalinan Normal, Pelatihan Klinik Persalinan Nornal, 2012, Jaringan Nasional Pelatihan KlinikKesehatan Reproduksi Departemen Kesehatan Republik Indonesia

Indrayani., Djami, M.E.U. 2016. Update Asuhan Persalinan dan Bayi Baru Lahir. Trans Info Media: Jakarta.

Karlina, S.D., Reksohusodo, S., Widayati, A. Pengaruh Pemberian Aromaterapi Lavender secara Inhalasi terhadap Penurunan Intensitas Nyeri Persalinan Fisiologis pada Primipara Inpartu Kala Satu Fase Aktif di BPM "Fetty Fathiyah" Kota Mataram.

Kivani, Maasumeh, Sara Azima, Narges Alavi, Mohammad Hossein Tabaei, 2014. The effect of lavender aromatherapy on pain perception and intrapartum outcome in primiparous women. Diakses 10 Agustus 2018 dari https://www.researchgate.net/pub lication/269516747_The_effect_of _lavender_aromatherapy_on_pain _perception_and_intrapartum_out come_in_primiparous_women

Susilarini, Winarsih, Sri., Idhayanti, R.I. 2017. Pengaruh Pemberian Aromaterapi Lavender terhadap Pengendalian Nyeri Persalinan Kala I pada Ibu Bersalin. Jurnal Kebidanan Vol. 6(12):47-54.

Cholifah, Siti., Raden, Abkar., Ismarwati. 2016. Pengaruh Aromatherapi Inhalasi Lemon terhadap Penurunan Nyeri Persalinan Kala I Fase Aktif. Jurnal Kebidanan dan Keperawatan Vo. 12 (1): 46-53. Universitas Muhammadiyah Sidoarjo.

Soetrisno, Astuti, L.A., Cahyanto, E.B., Sulistyowati, S.2016. Proceeding Seminar Nasional Kebidanan. Fakultas Kedokteran Universitas Sebelas Maret. Efektifitas Aromatherapy lavender dan jasmine terhadap Penurunan Nyeri 
Persalinan Kala I, Lama Persalinan Kala II dan Fetal Outcome. No. ISSN: 2528-4665.

Dolatian,M., Hasanpour, A., Montazeri, Sh., Heshmat, R., Majd, H.A. 2011. The Effect of Reflexologi on Pain Intensity and Duration of Labor on Primiparas. Iran Red Crescent Journal Vol 13(7): 475479.

Saputra, Lyndon, Anota Lockhart RN. MSN, 2014, Asuhan Kebidanan Masa Persalinan Fisiologis dan Patologis, Binaripa Aksara Publisher, Tanggerang Selatan.

Lakhan, S.E., Sheafer, H., Tepper, D., 2016. The Effectiveness of Aromatheraphy in Reducing Pain: A Systematic Review and MetaAnalysis. Jurnal Pain Research an Treament. Diakses tanggal 09Agustus 2018 from https://www.ncbi.nlm.nih.gov/pm c/articles/PMC4177623/

Suwanti, Susi., Wahyuningsih, Melania., Liliana, Anita.2018. Pengaruh Aromaterapi Lemon (Cytrus) terhadap Penurunan Nyeri Menstruasi pada Mahasiswawi di Universitas Respati Yogyakarta. Jurnal Respati Yogyakarta Vol 5 (1):345-349.

Namazi, M., Akbari, S..D.A.A., Mojab, F., Talebi., A., Majd, H.A., Jannesari., S. 2014. Effects of Citrus Aurantium (Bitter Orange) on The Severity of First-Stage Labor Pain. Iranian Journal of Pharmaceutical Research Vol 13(3): 1011-1018.

Sulastri, Mae Sri Hartati Wahyuningsih, Elsi Dwi Hapsari, Efek Pemberian Aromatherapy Jeruk Masam Terhadap Intensitas Nyeri Pasca Bedah Sesar. University Reasearch Colloqium STIKES PKU Muhammadiyah Surakarta. http://C:/Users/Lenovo/AppData/ Local/Temp/128-Article\%20Text244-1-10-20180222.pdf.

Yazdkhasti, Mansoreh, Arezoo Pirak, 2016. The effect of aromatherapy with lavender essence on severity of labor pain and duration of labor in primiparous women, Journal
Complementary Therapies In

Clinical Practice. Diakses tanggal 10 Agustus 2018 from https://www.sciencedirect.com/jo urnal/complementary-therapiesin-clinical-practice/vol/25/suppl/C 